\title{
Ivana Cindrić
}

University of Zagreb, Faculty of Teacher Education, Zagreb, Croatia ivana.cindric@ufzg.hr

\section{Vlatka Blagus}

American International School of Zagreb

vlatka.blagus@aisz.hr

\section{Young Croatian Heritage Language Learners' Reception of the Fairy Tale "Reygoch"}

Izvorni znanstveni rad / original research paper

Primljeno / received 16. 12. 2016. Prihvaćeno / accepted 10. 3. 2017.

DOI: 10.21066/carcl.libri.2016-05(02).0006

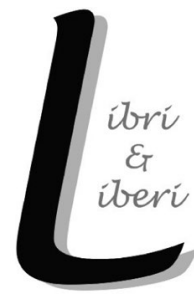

The paper presents the habits and attitudes of young Croatian heritage language learners (CHLLs) attending the American International School of Zagreb (AISZ) towards reading in general and towards reading fairy tales in Croatian and English. More specifically, their reception of the fairy tale "Reygoch" by Ivana Brlić-Mažuranić is considered. Although mostly bilingual, the CHLLs in this study follow the curriculum in the English language, and they attend Croatian Language and Literature classes. The curriculum for this subject, adapted to AISZ students' needs, introduces Croatian Tales of Long Ago by Ivana Brlić-Mažuranić in Croatian in the 4th grade. The results show that works of Brlić-Mažuranić can be offered for reading to young CHLLs, taking into consideration their specific reception. They also reveal the level of literary reading skills and describe the differences between students. Possible difficulties which students encounter in reading an authentic text, challenging at various levels of reading a literary text, are explained. Finally, the authors offer suggestions to help avoid such difficulties or at least to lessen them.

Keywords: c-test, fairy tale, reception, "Reygoch", young Croatian heritage language learners

\section{Introduction}

Present day technology has enabled people to establish a variety of relationships and connections at a global level without moving from the comfort of 
their home. Technology and travel opportunities have also influenced the ease with which people move to close, distant, even remote areas of the world while, at the same time, maintaining relationships with their family, relations and friends in their home country. These days, people's desire to move is powered not only by whim, curiosity, exploration, but by the nature of their work, professional opportunities, dislocations of businesses and companies, and the search for better opportunities. Over the last few decades, this has created a kind of global nomad. The term was coined by Norma McCaig in 1984, defining a person of any age or nationality who has lived a significant part of his or her developmental years in one or more countries outside his or her passport country because of a parent's occupation (Schaetti 1993). Such living has created the need for children to be educated in a way that provides them with a programme of study that is internationally common and recognised, regardless of where the students are or will be educated. Children who require such an education do not generally enter or plan to continue their education in the host country and often simply study the language of the host country as a foreign language by taking language acquisition classes.

Looking at the Croatian context, one school offering an international and American curriculum for children from pre-kindergarten to grade 12 for students on the go is the American International School of Zagreb (AISZ). For approximately $30 \%$ of the students attending AISZ, Croatian is a heritage language (HL), as those students are children of Croatian nationality or Croatian descent. Jelaska (2014) refers to heritage language learners (HLLs) as a subgroup of second language learners who acquire $\mathrm{HL}$ in the family or in the narrow language environment of a dominant language, and therefore they are in a broader sense bilingual. Due to their very limited instruction time in Croatian and their family background, Croatian Language and Literature students at AISZ mostly belong to the group of HLLs. For example, in grades 1 to 5 only $5 \%$ of the total language instruction is in Croatian. In grades 6 to 10 the percentage is higher, $12.5 \%$. The ratio of instruction time in Croatian and English with French / German shows that Croatian heritage language learners (CHLLs) at AISZ are not sufficiently exposed to the Croatian language in order to acquire it as Croatians in Croatian public schools, and they often need to learn it as second language learners (SLLs) do. Moreover, for AISZ CHLLs, English has become the dominant language for most social interactions even outside the school, with both peers and siblings. The course Croatian Language and Literature at AISZ bridges these gaps and provides its students with language to enable them to enter the Croatian school system at some point at primary, high school, or university level, or simply to work in Croatia. These students will receive an international primary and high school education with English as the language of instruction, but could potentially enrol in a Croatian university. 
In order to reconcile the specific needs of such CHLLs, the curriculum for Croatian Language and Literature encompasses both the international and Croatian curriculum. According to the Croatian National Educational Standard for Elementary School (Nastavni plan... 2006), one of the two obligatory literary works in grade four are the two fairy tales, "Stribor's Forest" and "Reygoch", from the Tales of Long Ago by Ivana Brlić-Mažuranić, first published in 1916, in Croatian. ${ }^{1}$ For the last ten years, the mentioned fairy tales have been introduced to AISZ students in the fourth grade. However, the difference in students' reception between the two fairy tales has been evident year after year. While "Stribor's Forest" would instantly engage students into the world of fantasy, generating much discussion from students, "Reygoch" was often received in a lukewarm manner, requiring additional explanations and contextualisation. We put forward some of the obvious explanations for such differences in the reception of the two fairy tales: length ("Reygoch" has almost twice the number of pages, 18 pages compared to 10 pages of "Stribor's Forest"); familiarity/likability of literary elements (themes, characters, or setting); teaching strategies and tools employed by the teacher; the phase of the school year, or even the season when the fairy tales are introduced (e.g. "Stribor's Forest" which takes place in winter is also introduced in the winter season, making it easy for students to sense the atmosphere and engage in the story; "Reygoch", on the other hand, is a story which takes place in summer but is read with students during the winter months, possibly making it difficult for students to sense the atmosphere in the fairy tale); and the students' various profiles (their specific readiness, interests, learning profiles). Even when the animated CD-ROMs Croatian Tales of Long Ago 1 and Croatian Tales of Long Ago 2 were used as instructional tools in the classroom for both fairy tales, students continued to demonstrate less engagement and comprehension with regard to "Reygoch" than to "Stribor's Forest". To what extent is the students' engagement based on their text comprehension? And to what extent is students' comprehension based on familiarity of vocabulary and context, and simplicity of syntax? These three categories (vocabulary, syntax and context) were considered as challenging factors for CHLLs while reading "Reygoch". ${ }^{2}$ If students' engagement and comprehension are highly correlated with these three categories, how would they be ranked? Furthermore, what makes "Reygoch" difficult for students to comprehend and carry

1 This collection of tales, originally titled Priče iz davnine, was translated into English by Fanny S. Copeland in as early as 1924, and received a wide and positive response in the English-speaking world (Narančić Kovač 2016).

2 "Reygoch" is about a giant and a little girl, Curlylocks (Regoč and Kosjenka in Croatian), who help unite two previously conflicting villages into one, so they could live in peace and pursue their common interests together. 
on reading? Many questions regarding the teaching of "Reygoch" have been raised over the past decade and this study has been conducted in an attempt to answer them.

\section{Theoretical frame}

Research related to the reception of works by Ivana Brlić-Mažuranić has mostly focused on the perception and reception of her work from the literary-theory point of view, i.e. with respect to the reception theory in literature. Such research has shed light on reception with respect to the social-historical context (e.g. Skok 1995, Ewers 2013, Jurišić 2014), or with respect to readers whose mother tongue is not Croatian (e.g. Hranjec 2010, Turza-Bogdan \& Kovač 2015, Grahovac-Pražić \& Marijić 2015). Furthermore, the majority of recent research has focused on BrlićMažuranić's first children's story The Strange Adventures of Hlapich the Apprentice.

In the field of Croatian second language acquisition, only research on literary texts in relation to adult learners has been conducted. One of the newest products of such research is the first complete adaptation of Šegrt Hlapić for B1 level (Grgić, Đurđević and Salak 2015) by Croaticum's ${ }^{3}$ lecturers. This paper will reveal yet another group of language learners, young Croatian heritage learners, and their reception of literary works by Ivana Brlić-Mažuranić. It is hoped it will add to the richness of research in the domain of literature and language.

\section{Aims and research methodology}

The research mentioned, or lack of research, prompted us to study a group of Croatian heritage language learners (CHLLs) at AISZ. The research conducted would provide insight into the habits and attitudes students have towards the fairy tale as a genre and in particular students' reception of the fairy tale "Reygoch". More precisely, with this research, we aimed to establish the following:

1. Young Croatian heritage language learners' (CHLLs) reading habits in Croatian and English;

2. Young CHLLs' attitudes towards the fairy tale genre and the fairy tale "Reygoch";

3. Young CHLLs' reception of the fairy tale "Reygoch" and their comprehension of an excerpt from the fairy tale.

Finally, based on the research findings, the aim was to provide suggestions and strategies to help CHLLs improve their reception and comprehension of fairy tales

\footnotetext{
3 Croaticum - Centre for Croatian as a Second and Foreign Language at the Faculty of Humanities
} and Social Sciences, University of Zagreb. 
in general, but in particular Croatian fairy tales. The research results were expected to disclose successful aspects of students' reception of fairy tales, but also aspects which are complex and therefore challenging for second language learners.

\section{Research questions}

According to the aims of the research, the following research questions were set:

1. Do young Croatian heritage language learners read more in English or Croatian?

2. What attitudes do Croatian heritage language learners have towards the fairy tale genre, Croatian and English fairy tales and the fairy tale "Reygoch"?

3. What is the difference between young CHLLs' reception of the fairy tale "Reygoch" with respect to their grade level, number of years out of the Croatian school system, and mother tongue(s)?

4. What is the difference between young CHLLs' comprehension of the fairy tale "Reygoch" with respect to students' grade level, number of years out of the Croatian school system, and mother tongue(s)?

\section{Sample of participants}

The sample of participants included students $(\mathrm{N}=30)$ of the American International School of Zagreb who attend the Croatian Language and Literature course. In terms of gender, the sample of participants was distributed almost equally, i.e. 14 male and 16 female participants. The distribution of participants in grades was the following: grade six -7 students, grade seven -9 students, grade eight -4 students, grade nine -4 students and grade ten -6 students. Because of the relatively small sample size and uneven distribution of students per grade level, in the analysis of results, students were grouped into middle school students (20) and high school students (10). All the students in grades 6 to 10 have Croatian Language and Literature lessons of 90 minutes, two/three times per week alternatively. The research was conducted in September 2016, almost a month into the school year.

\section{Instruments}

Three instruments were used for the purpose of this research. The first instrument was a 3-part questionnaire with the first part providing general information about the participants, i.e. student bio-data (part A). In the second part of the questionnaire (part B), participants were provided with questions and statements on a 5-point Likert scale to elicit student habits and attitudes with respect to reading in Croatian and in English and their attitudes and perception of the fairy tale genre in general. It also provided data on students' perception of the fairy tale "Reygoch". Finally, the third part of the questionnaire (part C), which was completed upon reading an 
excerpt from the fairy tale "Reygoch", provided information on students' reception of the text and aspects of the fairy tale with which they expressed their degree of agreement.

The second instrument used in the research was a six-page handout containing the first of the two original parts of the fairy tale "Reygoch" (Brlić-Mažuranić 2006) which students were to read independently in class. While reading, students were encouraged to circle or underline words or expressions they found unusual or unknown. Given that the students are at various proficiency levels, the instructor/ researcher suggested that students should try to read as much as they could, but insisted that they all read the first page.

The final, third instrument was an assessment in the form of a c-test. The c-test is a series of short texts prepared for testing by deleting the second half of every second word (Read 2000: 111). Its intention is to assess general proficiency in the language, particularly for selection and placement purposes, and the deletions should be a representative sample of all the elements in the text (Klein-Braley 1985[1997]: 63-66 as cited in Read 2000). For the purpose of our research, two initial paragraphs from the fairy tale "Reygoch" were chosen for the c-test. The second half of every second word was omitted, thus making 21 omissions in the first paragraph (Task 1) and 20 omissions in the second paragraph (Task 2). The rationale for using a c-test rather than some other type of test for testing as indicated by Katona and Dörnyei (1993) is that more items can be included since we were using shorter paragraphs, easy and objective scoring, a more representative sample of different parts of speech, and students enjoy doing c-tests. Finally, deleting the second half of a word might suggest that knowledge of word formation and sentence structure is more important in this kind of test than, for example, semantic aspects of vocabulary, especially if the language being tested has a complex system of word endings (Read 2000: 111) as is the case with Croatian. Therefore, this instrument was used to determine the students' language comprehension of a recently read text. After reading "Reygoch", students were instructed to first answer the third part of the questionnaire (part C), then to fill in the blanks in the two paragraphs. All three instruments (questionnaire, excerpt from the fairy tale "Reygoch", and the c-tests) were coded in order to establish a correlation between the tested variables in the research.

\section{Procedure}

The research was carried out in a regular classroom setting. Students from grades 6-10 who attend Croatian Language and Literature courses at AISZ are 
divided into 4 groups. Grade 6 and grade 7 students have a joint lesson. During the 90 minutes (double lesson) students were given the 3-part questionnaire, the reading assignment - the first chapter of "Reygoch", and the final task, the c-tests. The teacher allocated a maximum of 30 minutes for the completion of each of the tasks, but most students handed in all their answers in 60 minutes.

All students who participated had parental permission to do so. Through a written consent form, parents were informed about the nature of the research and its purpose. Data were entered into the SPSS 17.0 statistical program and were analysed using descriptive statistics, t-tests, non-parametric tests for independent samples and content analysis.

\section{Results and discussion}

As students attending AISZ are a highly mobile group of students in terms of moving to different countries and educational systems, we wanted to establish the number of years this population has been out of the regular Croatian system of education. Because of the small sample size and uneven distribution of participants according to the number of years away from the Croatian school system, the researchers created two categories for this variable: students who have been out of the Croatian school system from 1-4 years and those out of it for 5+ years. As a result, the distribution of students was the following 1-4 years: 15 students, and 5+ years: 15 students. In the analysis of results, this kind of a categorisation might indicate whether there are statistically significant differences between students who have been away from the Croatian school system for shorter or longer periods, and variables such as habits, attitudes and reception.

The language of instruction at AISZ is English; however, keeping in mind the variety of national backgrounds of students in our sample as bilinguals with some possible multilinguals, we also wanted to establish what language(s) the students speak in the home environment. Based on the students' responses, their answers were grouped into three major categories: Croatian only, Croatian +1 or more languages, and other (a language other than Croatian). The distribution of languages spoken at home can be seen in Table 1.

Having correctly anticipated that in the last two years CHLLs would have read more in English, we wanted to find out whether the situation was somewhat different over a longer period of time (six years). Fig. 1 shows the number of books students have read in the Croatian language over the last six years. Most students reported they do not read more than two books in Croatian per year, which is an unexpected finding because most students have been enrolled in Croatian Language 
Table 1. Distribution of languages students speak in the home environment.

Tablica 1. Distribucija jezika koje učenici govore kod kuće.

\begin{tabular}{|c|c|c|c|c|}
\hline & Frequency & Percent & $\begin{array}{c}\text { Valid } \\
\text { Percent }\end{array}$ & $\begin{array}{c}\text { Cum. } \\
\text { Percent }\end{array}$ \\
\hline Croatian only & 11 & 15.7 & 36.7 & 36.7 \\
\hline Croatian +1/more & 14 & 20.0 & 46.7 & 83.3 \\
\hline Other & 5 & 7.1 & 16.7 & 100.0 \\
\hline Total & 30 & 42.9 & 100.0 & \\
\hline
\end{tabular}

and Literature classes for at least two years, in which they had to read at least eight novels in Croatian. Although the distribution of students' answers is varied, further analysis showed no statistically significant differences with respect to the school department (middle school / high school); the number of years out of the Croatian school system (one to four / more than four), or mother tongue(s) spoken at home (Croatian only / Croatian +1$)$.

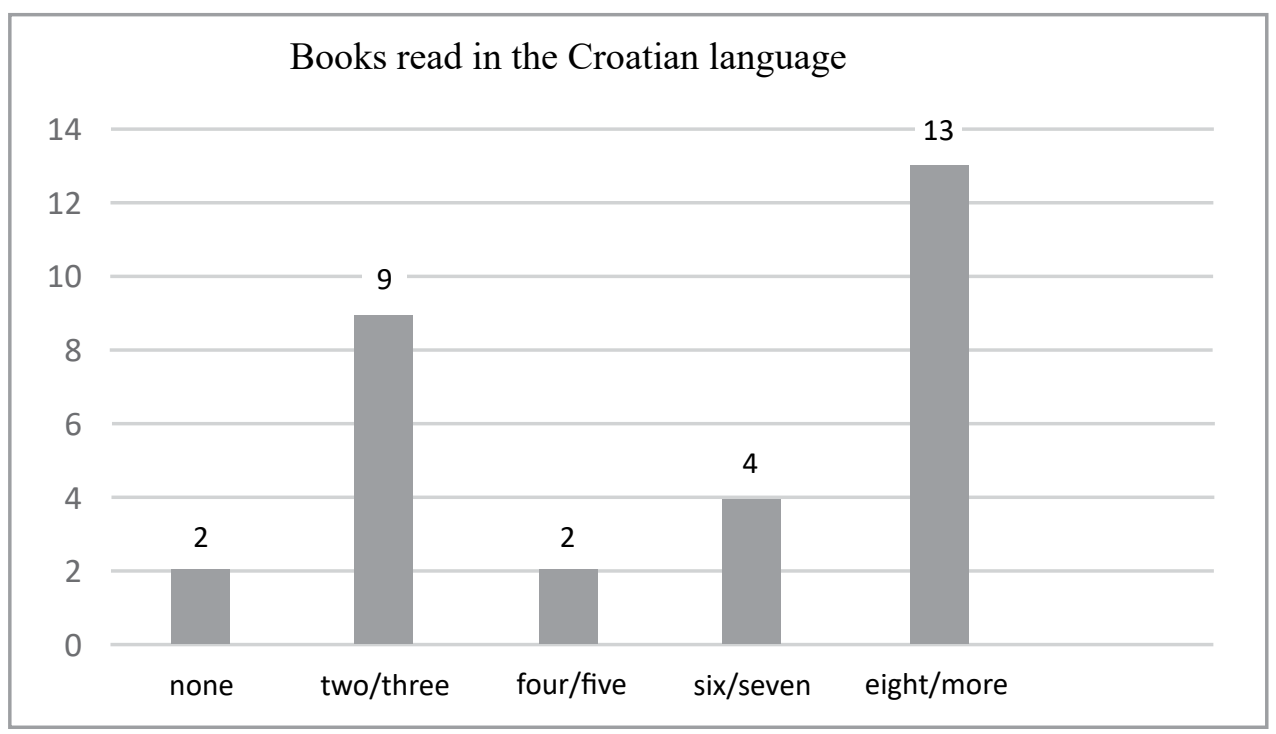

Fig. 1. Distribution of books read in the Croatian language over a period of six years.

SI. 1. Distribucija broja knjiga na hrvatskome jeziku pročitanih tijekom šest godina. 
Table 2. Mean values for students' attitudes towards the fairy tale genre, Croatian fairy tales, and fairy tales in English.

Tablica 2. Srednja vrijednost stavova učenika prema bajci kao žanru, hrvatskoj bajci i bajci na engleskome jeziku.

\begin{tabular}{|c|c|c|c|c|c|}
\hline & $\mathrm{N}$ & Min. & Max. & Mean & Std. Deviation \\
\hline Fairy tale genre & 30 & 1 & 5 & 3.40 & 1.192 \\
\hline IBM's fairy tales in Croatian & 30 & 1 & 4 & 2.70 & 1.022 \\
\hline Fairy tales in English & 30 & -1 & 5 & 3.87 & 1.224 \\
\hline Valid N & 30 & & & & \\
\hline
\end{tabular}

The second part of our questionnaire focused on students' attitudes towards the fairy tale genre. It included attitudes students have towards Croatian fairy tales, more specifically fairy tales by Ivana Brlić-Mažuranić and fairy tales in the English language, and their perception of the fairy tale "Reygoch".

The mean values of students' reports of their attitudes towards the fairy tale genre, fairy tales by Ivana Brlić-Mažuranić in the Croatian language, and fairy tales in the English language are reported in Table 2. The students in our sample show an indifferent attitude towards the fairy tale as a genre $(\mathrm{M}=3.4)$, i.e. they neither like nor dislike them. The situation is slightly different in terms of Croatian fairy tales, where the analysis shows that they mostly do not like Croatian fairy tales $(M=2.7)$. The rather negative perception of Croatian fairy tales could be ascribed to insufficient, partial or inadequate exposure to the mentioned fairy tales throughout their education or upbringing, leading to the perception they report. What is more, fairy tales by Ivana Brlić-Mažuranić in the Croatian language are very rich in stylistic aspects (description, rhythm, idiolect), and in linguistic aspects (vocabulary, phraseology, syntax, etc.), making them somewhat more challenging for CHLLs to read than fairy tales in the English language which are abundant and presented in numerous reader-friendly ways. The mean value for attitudes towards fairy tales in the English language was calculated at $\mathrm{M}=3.87$, again indicating that even fairy tales which are written in the language of instruction and in which students read more often do not seem to inspire a like or even a dislike for that matter. 


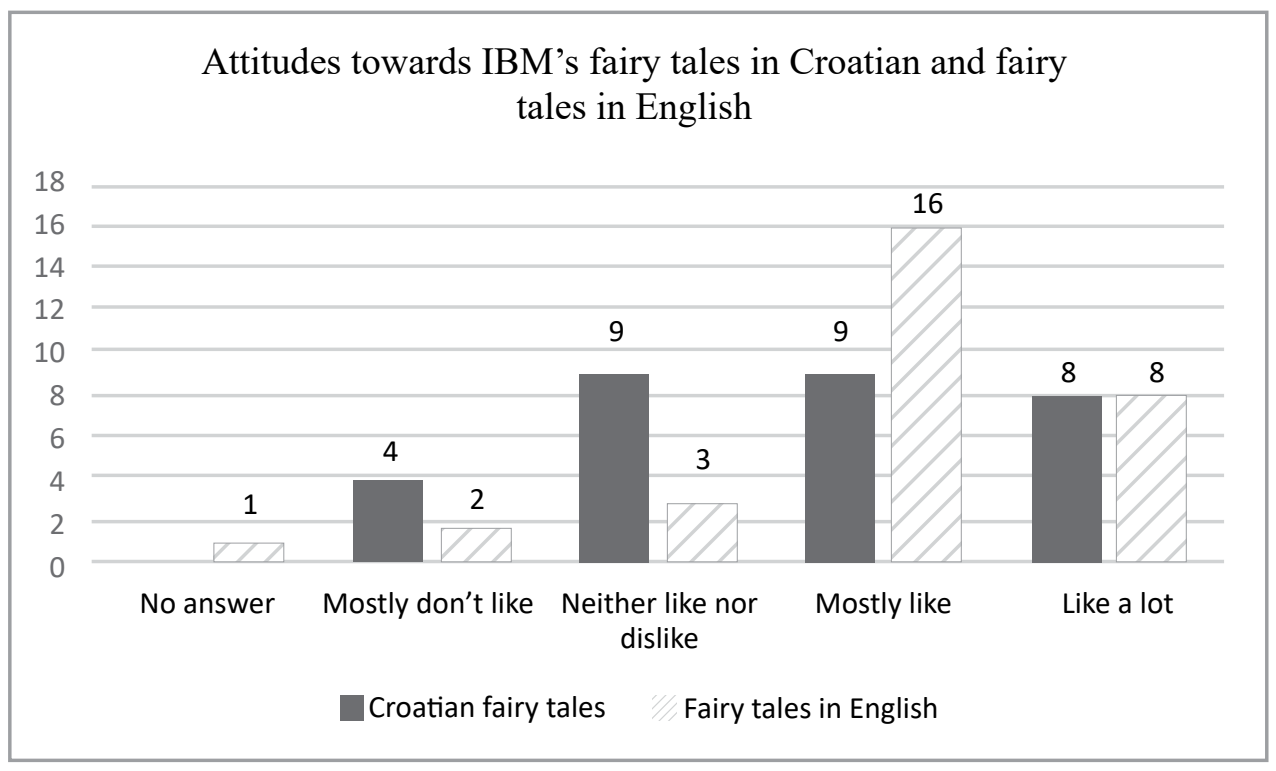

Fig. 2. Comparison of students' attitudes towards Brlić-Mažuranić's fairy tales in Croatian and fairy tales in the English language.

S1. 2. Usporedba stavova učenika o bajkama Ivane Brlić-Mažuranić na hrvatskome jeziku i bajkama na engleskome jeziku.

Fig. 2 gives a visual comparison of students' attitudes towards Croatian fairy tales and fairy tales in the English language. Although students express a general liking of fairy tales written in the English language, they do not disregard or reject Croatian fairy tales entirely. There is evident indifference, but more positive than negative attitudes.

Considering the variety of students' backgrounds in terms of the number of years out of the Croatian school system, the researchers wanted to find out how many students were familiar with the fairy tale "Reygoch", and how they liked it. Almost half of the participants $(\mathrm{N}=13)$ were familiar with the fairy tale, while 12 participants were not, and the remaining 3 participants could not recall. Of the 13 students who had read "Reygoch" or were familiar with it, 8 students liked it a little, while 4 neither liked it nor disliked it and 1 student did not like it at all. Students who had not read the fairy tale were asked to report their expectation of the fairy tale. In the analysis of this question, more answers were reported than expected, indicating that some students who had either read the fairy tale or were familiar with it also expressed their expectation, perhaps because they misunderstood the question or perhaps they had a different expectation for this particular reading session. The distribution of their answers is the following: 4 students reported that they would not like it at all, 2 students said they would not like it, 8 students were indifferent 
in their reply, 5 students said that they would like it a little, and 2 students said that they would like it a lot. This is a similar distribution to the students' liking of Croatian fairy tales in general.

According to the students' responses to the question "Have you read any other fairy tales by Ivana Brlić-Mažuranić?", 13 students reported having read some of her works, while the remaining 17 students had not read any, or could not recall. Some of the fairy tales students mentioned were: "Stribor's Forest", "Little Brother Primrose and Sister Lavender", Tales of Long Ago, and Wild Horse (which is a tale by Božidar Prosenjak, and not by Brlić-Mažuranić). Those students who had been at the school since grade 4 would probably recall having read "Stribor's Forest", and those students who had been in a Croatian school system in the higher grades would most certainly recall having read Tales of Long Ago in grades 6, 7. It is also not wrong to assume that, being heritage language learners, some students would have been exposed to the fairy tales by reading them in the home environment.

Guided by the schema theory which is based on Kenneth S. Goodman's model of reading as a guessing game (1967), i.e. that evoking schema aids comprehension, prior to engaging in reading the fairy tale, students were asked if they could make some associations for the title of the fairy tale "Reygoch". One assumption about schema activation is that some words, or groups of words, or the title of a text, are highly suggestive and can signal a certain schema (An 2013). Students' answers are presented in Fig. 3. Although the answers vary, we can categorise them as associations with a giant (monster), a feature from nature (plant, forest, tree, stream, field, mushroom), a name (character, boy, animal), and a sound. One student mentions an association with the sound of a frog, which from the point of view of an English speaker would be "ribbit ribbit" or "breedeet breedeet", but the Croatian cross-linguistic onomatopoeia would be "rega rega", indicating the possible influence of the Croatian language for this particular student. Three students could not associate the title with anything, while five students reported not being able to make an association as they struggled with the meaning of the word.

Students' responses regarding some aspects of fairy tales were tested in order to establish what makes an interesting fairy tale for Croatian heritage language learners. On a 5-point Likert scale ( $1=$ not important at all; $2=$ not important; $3=$ =neither important nor unimportant; 4=mostly important; 5=very important) students reported their opinion in terms of the importance of a particular fairy tale feature. Table 3 shows that the variables exciting plot, convincing dialogues, words and expressions I can understand, and unpredictable ending are for them the important characteristics of an interesting fairy tale. This suggests that in order for students to read a fairy tale, it should have an interesting action (plot), convincing dialogues 


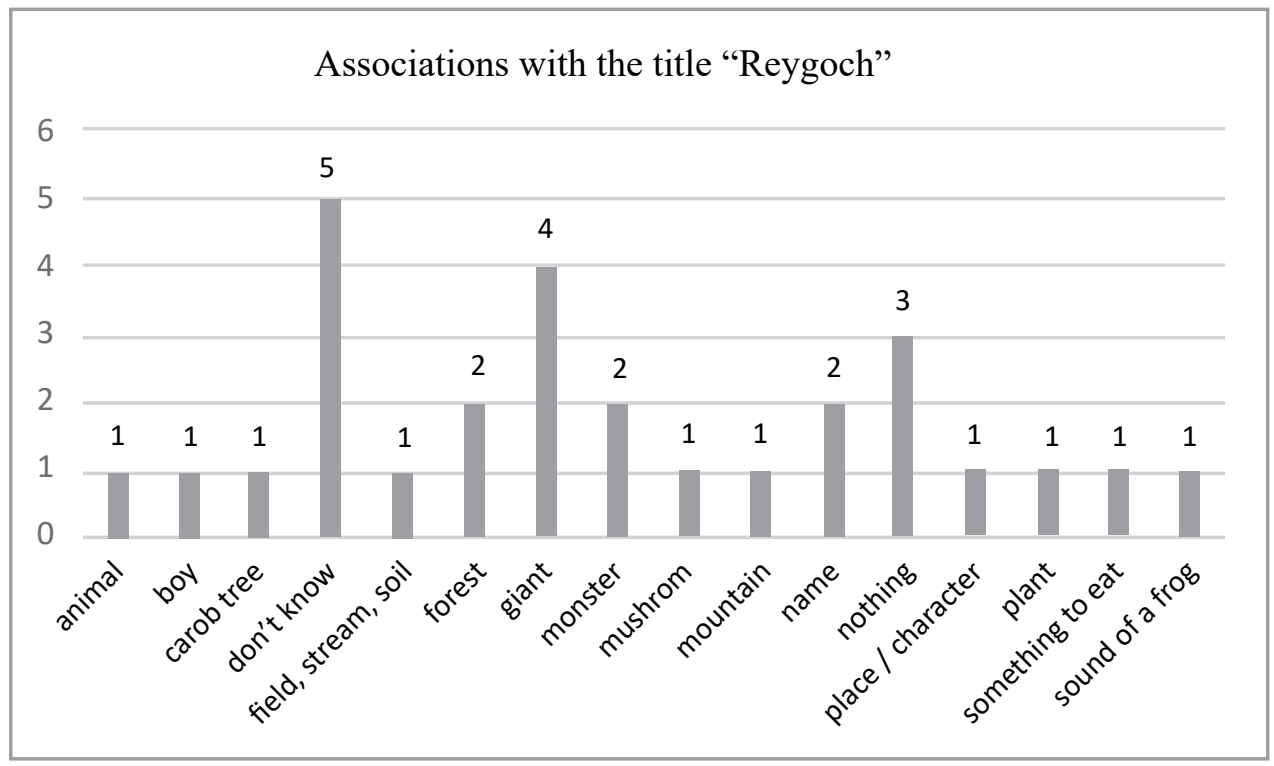

Fig. 3. Associations with the title "Reygoch".

Sl. 3. Asocijacije uz naslov „Regoč“".

unburdened by unfamiliar words and expressions, and have an unpredictable ending. Other characteristics of fairy tales, such as rich descriptions of time and place $(\mathrm{M}=3.70)$, rich character descriptions $(\mathrm{M}=3.87)$, a moral $(\mathrm{M}=3.83)$, rich illustrations $(\mathrm{M}=3.27)$ were neither important nor unimportant for this sample of participants. Students' indifference to the aesthetic presentation of fairy tales is, however, particularly important for teachers, as this creates a space for resorting to strategies, activities and tasks which will help students understand and consequently appreciate the significance of the mentioned features. The engagement of teachers in this case is crucial in order for students not only to overcome potentially difficult language, but to have a better understanding of characters, the setting, to make and create associations, explore illustrations, inquire, predict, and discuss the moral of the fairy tale.

Upon reading the excerpt from the fairy tale "Reygoch", students were asked to report their reception (general liking, motivation to read on, understanding) of the first pages of the fairy tale. Their reports are presented in Fig. 4. Five students did not provide an answer to this question, which could be attributed to a simple omission. Only six students in the sample answered that they did not like the beginning of the fairy tale, while four students were indifferent. Nine students liked the beginning a little, and six students mostly liked the beginning. It could be said that for half of 
Table 3. Students' opinions of the importance of aspects of fairy tales.

Tablica 3. Učenički stavovi o važnosti pojedinih aspekata bajki.

\begin{tabular}{|l|l|l|l|l|l|}
\hline Variable & $\mathbf{N}$ & Mean & Std. Dev & Min. & Max. \\
\hline Exciting plot & 30 & 4.27 & .69 & 3.00 & 5.00 \\
\hline Rich description of time and place & 30 & 3.70 & .84 & 2.00 & 5.00 \\
\hline Rich character description & 30 & 3.87 & 1.07 & 1.00 & 5.00 \\
\hline Convincing dialogues & 30 & 4.20 & .89 & 2.00 & 5.00 \\
\hline Words and expressions I can understand & 30 & 4.33 & .76 & 3.00 & 5.00 \\
\hline Unpredictable ending & 30 & 4.37 & 1.00 & 1.00 & 5.00 \\
\hline Moral & 30 & 3.83 & .91 & 2.00 & 5.00 \\
\hline Rich illustrations & 30 & 3.27 & 1.62 & 1.00 & 5.00 \\
\hline
\end{tabular}

our sample (15 participants), the reception of the initial part of the fairy tale was rather positive, while the rest of the sample is not purely negative. Rather, it is distributed across dislike (6 students), indifference (4 students) and 5 students who did not provide an answer to this question. The mean value for students' answers is $M=1.8$ indicating that the sample liked the initial part a little. This kind of a result indicates that the reception of the fairy tale is on the positive side. However, in order to strengthen that reception, preparatory, pre-reading activities (explanation of words, discussions, description of context) should be conducted, regardless of the students' age and grade level.

Table 4 shows the mean values of the variables relating to particular aspects of the students' reception of the fairy tale. According to the students' responses, it seems that they were rather indecisive in determining whether the fairy tale motivated them to read on $(\mathrm{M}=3.27)$. This finding indicates that in order for students to read on, efforts should be made by the teacher not only before the actual reading, but after reading the initial part in order for students to reflect, explain and discuss the introduction, visualise the setting, the characters, discuss character descriptions and make predictions.

An unexpected finding in respect of the students' comprehension reports was that they mostly understood $(M=2.50)$ the fairy tale, regardless of the words that were unfamiliar to them and regardless of the unusual word order $(M=2.43)$. These 


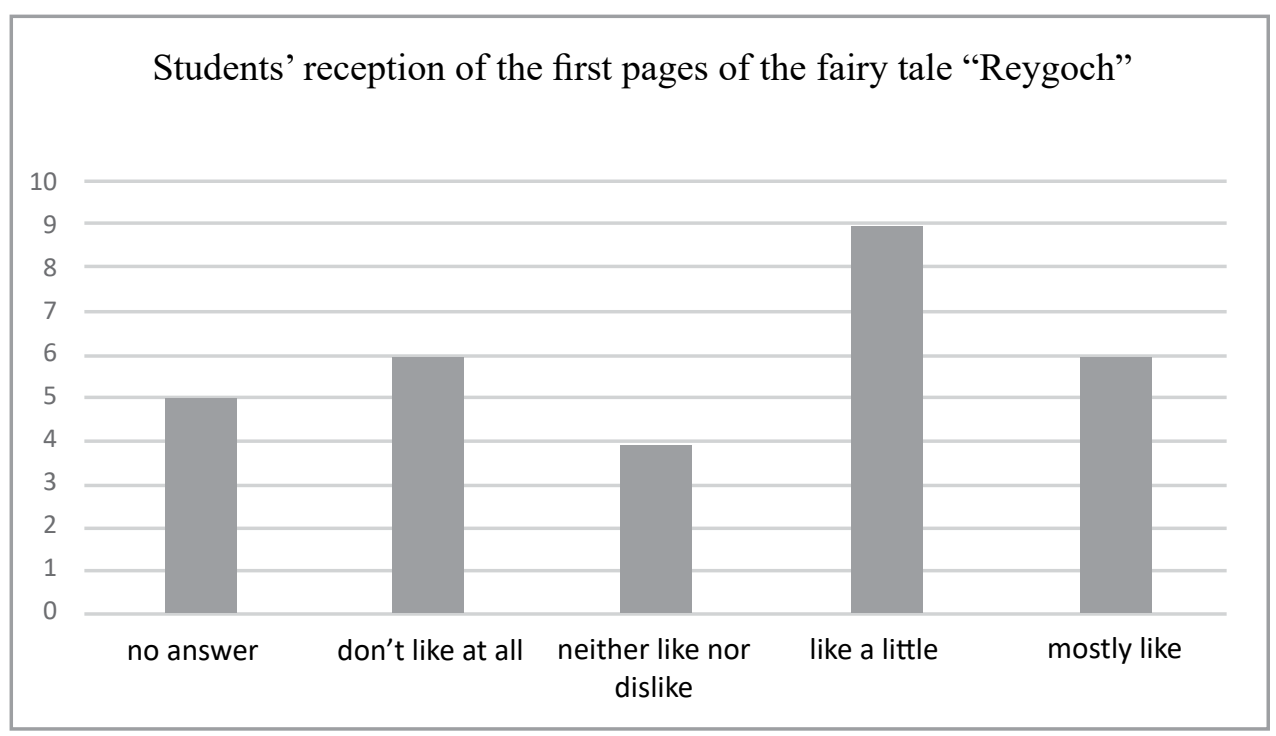

Fig. 4. Students' reception of the initial part of the fairy tale "Reygoch".

SI. 4. Učenička recepcija uvodnoga dijela bajke „Regoč“.

answers will be explored further when they are analysed in comparison with the results of the students' assessment. Furthermore, students were rather undecided in their responses with respect to having to watch the animated version of the fairy tale in order to understand the story $(\mathrm{M}=3.10)$.

Table 4. Students' reception of particular aspects of the fairy tale.

Tablica 4. Učenička recepcija određenih aspekata bajke.

\begin{tabular}{|l|l|l|l|l|l|}
\hline & N & Min. & Max. & Mean & $\begin{array}{l}\text { Std. } \\
\text { Deviation }\end{array}$ \\
\hline The beginning motivates me to read on. & 30 & -1 & 5 & 3.27 & 1.461 \\
\hline $\begin{array}{l}\text { I understand the fairy tale regardless of unknown } \\
\text { words. }\end{array}$ & 30 & -1 & 5 & 2.50 & 1.503 \\
\hline I understand the fairy tale regardless of word order. & 30 & 1 & 5 & 2.43 & 1.278 \\
\hline To understand one should see the animated film. & 30 & 1 & 5 & 3.10 & 1.583 \\
\hline "Reygoch" should be obligatory reading in school. & 30 & 1 & 5 & 3.70 & 1.236 \\
\hline I would recommend "Reygoch" to my friends. & 30 & 1 & 5 & 3.77 & 1.223 \\
\hline Valid N & 30 & & & & \\
\hline
\end{tabular}




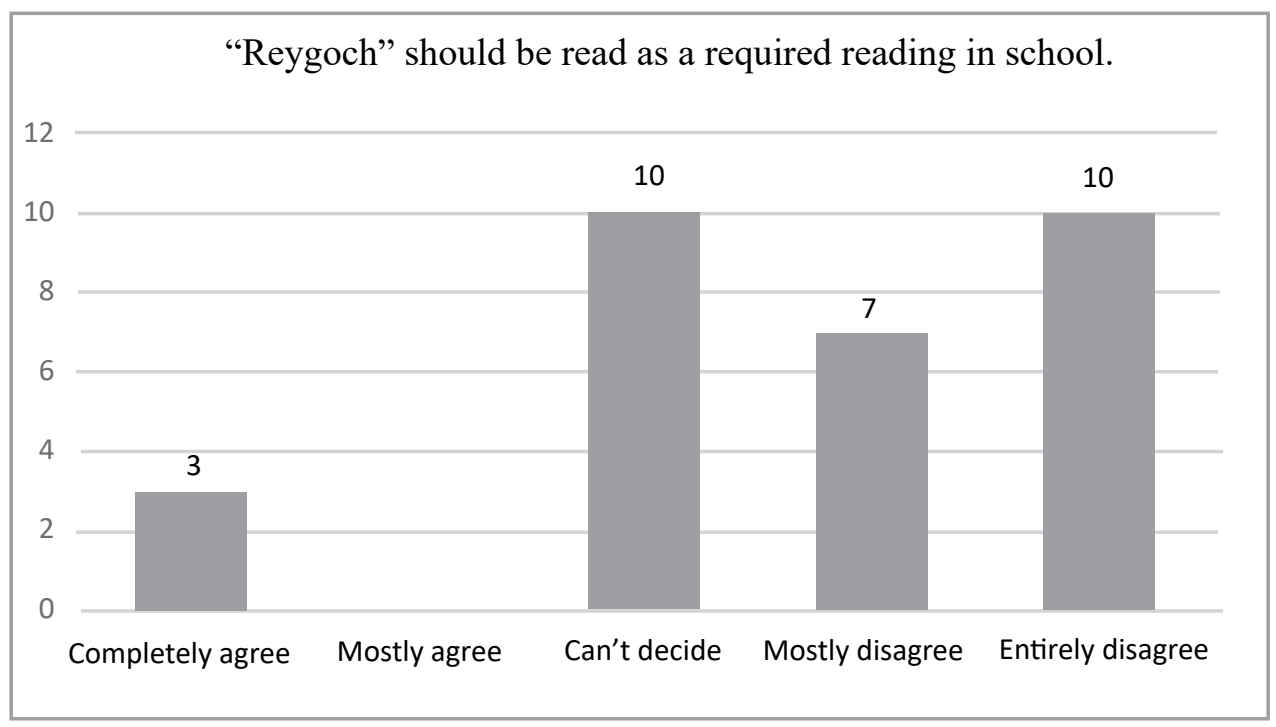

Fig. 5. Students' opinion's of whether "Reygoch" should be required reading in schools.

SI. 5. Učenički stavovi o tome bi li bajka „Regoč“ trebala biti uključena u školsku lektiru.

The same attitude was shared with respect to whether "Reygoch" should be obligatory reading in school $(\mathrm{M}=3.70)$ and whether they would recommend the fairy tale to their friends $(M=3.77)$. In other words, students were undecided about whether "Reygoch" should be obligatory reading in school and whether to recommend the fairy tale to their friends. The breakdown of students' answers regarding the variable "Reygoch" should be obligatory reading in school is presented in Fig. 5.

For the following variable, "I would recommend 'Reygoch' to my friends", the mean value was measured at $M=3.77$, indicating the students' indifferent attitude. The distribution of students' answers is shown in Fig. 6.

In similar research conducted on a sample of 100 fourth-grade students in primary schools in Croatia regarding their reception of the fairy tales "Reygoch" and "Stribor's Forest" (Turza-Bogdan and Kovač 2015), almost 73\% of the students would assign these fairy tales as required reading and $67 \%$ would highly recommend them to their friends. Compared to the sample in our research, it is evident that there is a degree of uncertainty with respect to whether "Reygoch" should be obligatory reading and whether students would recommend this fairy tale to their friends. The difference could be explained by the size of the sample in this research. However, we could also say that Croatian heritage language learners are indecisive as they 


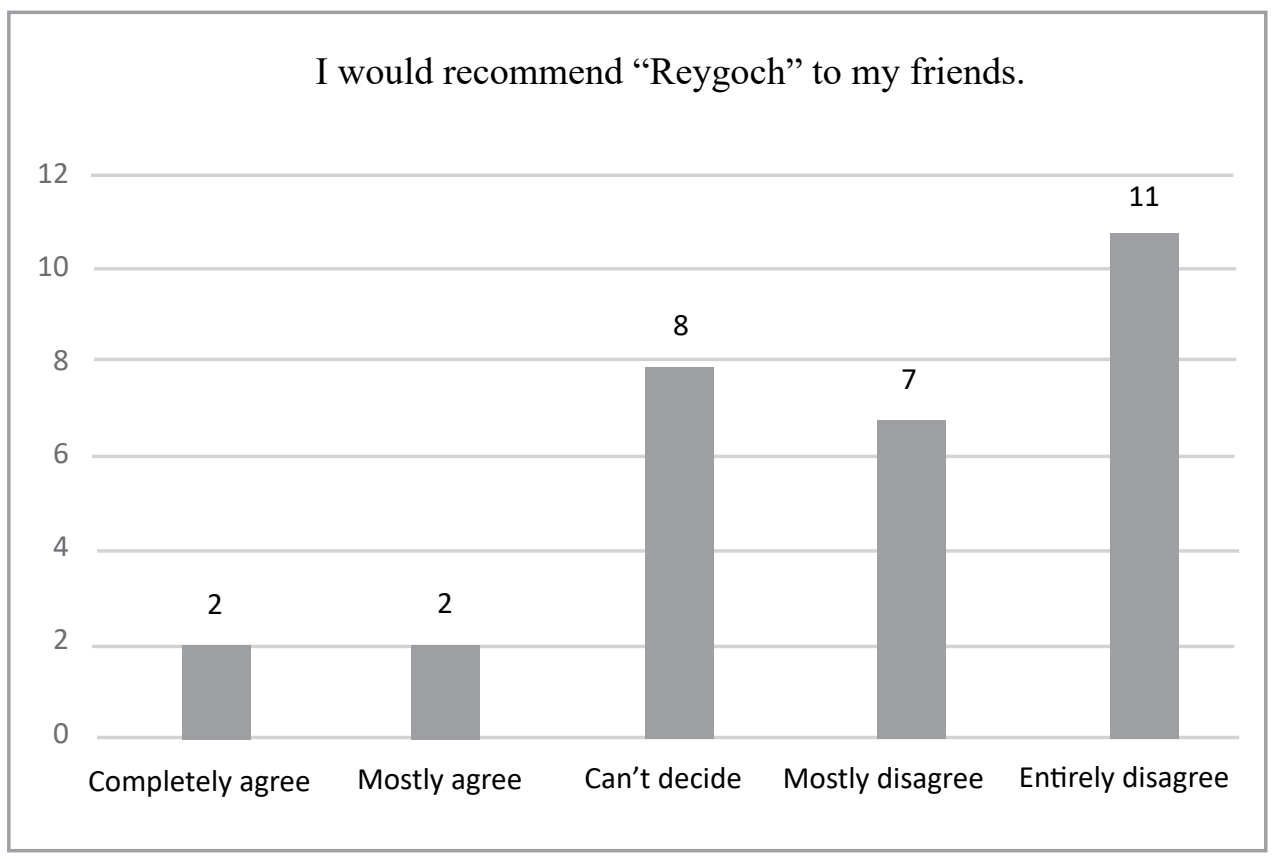

Fig. 6. Students' opinions on recommending "Reygoch" to their friends.

Sl. 6. Učenički stavovi o preporučivanju bajke „Regoč“ prijateljima.

lack continuity or authenticity in their exposure to Croatian fairy tales. This could be attributed to their learning environment which is not Croatian and therefore does not provide a natural context for reading Croatian fairy tales. Still, they sense that this is an area they should be familiar with. The second difference is that the participants in our sample were somewhat older than the participants in the research by Turza-Bogdan and Kovač (2015) which leads us to the question "What grade would you recommend 'Reygoch' to be read in?".

According to the results presented in Fig. 7, students generally recommend "Reygoch" for reading in the lower grades of primary school (grades 3, 4, and 5). In the research conducted by Turza-Bogdan and Kovač (2015), the results show that grade 4 students find "Reygoch" and "Stribor's Forest" as acceptable reading at the level of reception and they have a positive attitude towards the two fairy tales. Furthermore, as required reading in Croatian schools, "Stribor's Forest" and "Reygoch" are set to be read in grade four. The rest of the collection of Tales of Long Ago is intended for reading and interpretation in the sixth grade in the Croatian National Educational Standard (Nastavni plan i program... 2006). Based on the opinions of students in our sample, it seems that they generally agree in recommending "Reygoch" for reading in grades 3-5, i.e. in the upper primary grades or lower middle schools grades. 


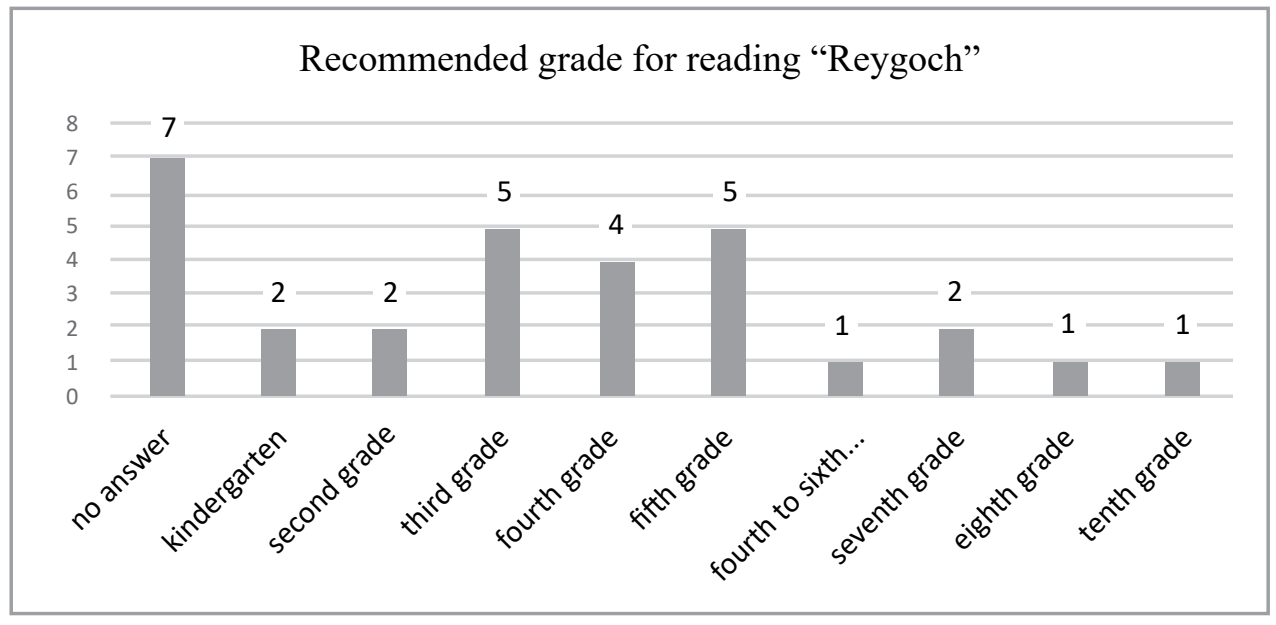

Fig. 7. Students' recommendations for grade level in which "Reygoch" should be read.

SI. 7. Učeničke preporuke o tome u kojemu bi se razredu trebala čitati bajka „Regoč“.

This only confirms the authors' observation that creating an appropriate classroom environment for introducing the fairy tale, introducing the fairy tale during a season that matches the fairy tale most appropriately, or during the particular phase of the school year (avoiding mid-term, half-term, school-break periods which can be rather stressful or distracting for students), and taking into consideration the students' backgrounds and language proficiency may actually contribute to a better reception of the fairy tale "Reygoch" in grade four or five.

The final part of the research was an assessment of the students' comprehension of the text presented in the form of a c-test. The results of the first c-test, i.e. the first paragraph of "Reygoch", showed that the students were able to solve this test with a very high degree of accuracy. Therefore, the students' opinions of the statements "Reygoch can be understood regardless of the unknown vocabulary" and "Reygoch can be understood regardless of the unusual word order", presented in Fig. 8, do not seem to deviate much from their performance on the assessment part.

The maximum number of points for the first assessment task was 21 and the calculated mean value was $M=18.13$ (min. 4 and max. 21). An analysis of the students' errors shows that the students understand the text and sentence context, as they were able to produce appropriate and correct words. The majority of errors were of an orthographic nature. For example, there were two occurrences of the error "*nočil" (instead of "noći") and four instances of "*noch $\underline{c}$ " which show insecurity in applying diacritics. There were also some spelling mistakes such as "*najživnjeg" or "*najživjeg" when the correct answer was "najživljeg". Another error that was 


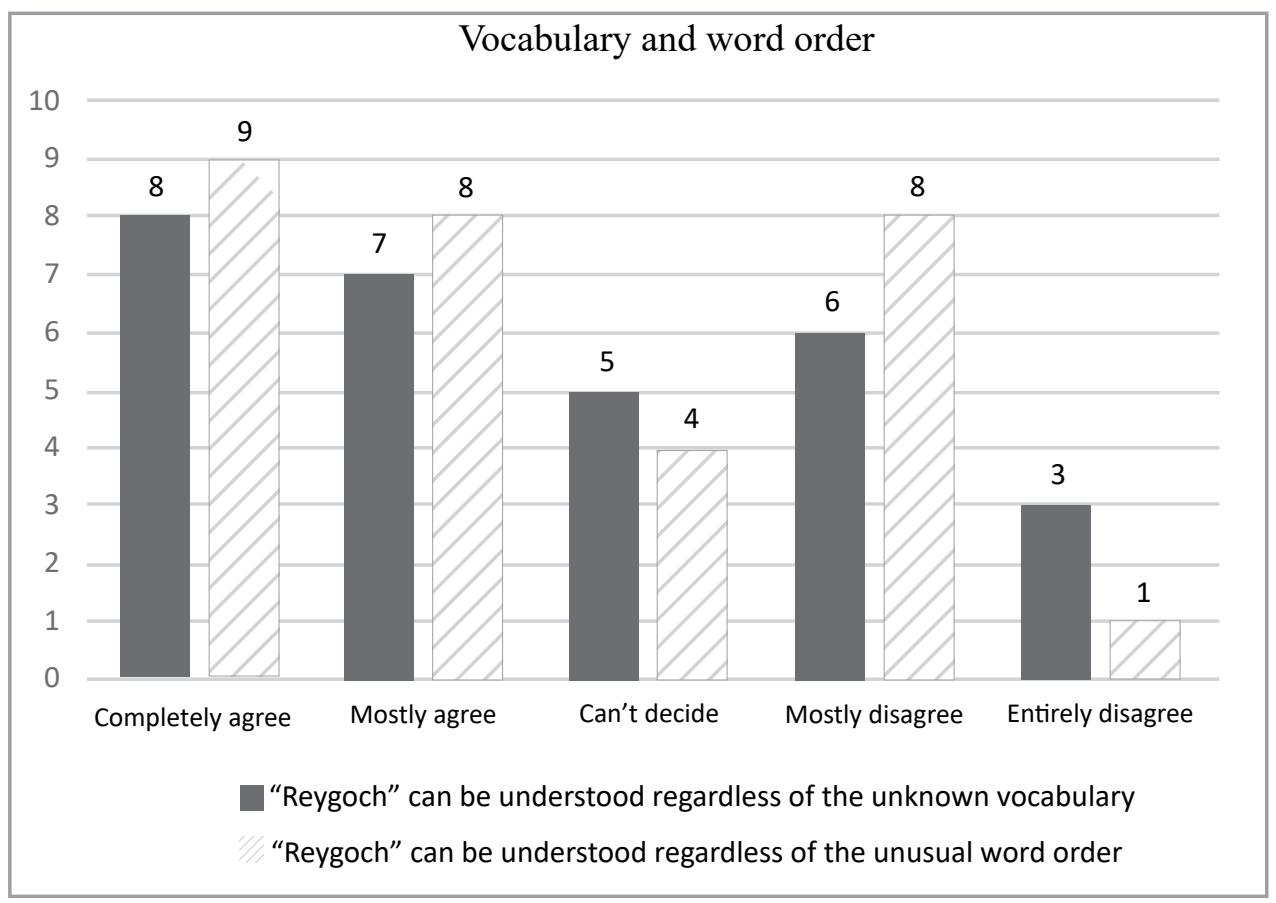

Fig. 8. Students' opinions of the influence of vocabulary and word order on text comprehension.

SI. 8. Učenički stavovi o utjecaju rječnika i reda riječi u rečenici na razumijevanje teksta.

observed, although not frequently, was the use of the very common phrase (simile) "ljut kao vrag" ('angry as a devil') instead of "ljut kao vatra" ('angry as fire', as used in the original fairy tale).

The results of the second c-test were somewhat lower, i.e. the mean value was $\mathrm{M}=14.48$ (min. 0, max. 20). Lower scores on the second c-test could possibly be attributed to a lack of time, the lack of challenge or "saturation" with a very similar task done twice, or perhaps the fact that the first c-test "mutilated" the first paragraph of the fairy tale which students generally read with more attention and focus.

Whether the scores differed with respect to grade level, i.e. middle school students and high school students, was calculated by applying the Mann-Whitney $\mathrm{U}$ test. The test showed that the result from the second c-test was statistically significantly higher for high school students $(\mathrm{M}=21)$ than for middle school students $(\mathrm{M}=12.30)(\mathrm{U}=36.000, \mathrm{p}=0.009)$. The difference between the results of high school students and the results of middle school students in the first c-test was not significant. What does this result tell us? 
Because of the relatively marginal difference in scores in the first c-test between the two groups (middle and high school), we can assume that the difference which occurred in the second c-test can be ascribed to the middle school students' requiring more time to complete the second task. Alternatively, it might be assumed that all the students were simply more confident in solving the first task as they remembered more information coming from the first paragraph of the fairy tale.

In order to find out whether there was a difference in the students' background, i.e. number of years at school and students' achievement in the c-test, we conducted another Mann-Whitney U test for independent samples. Students were grouped according to the number of years they had been educated out of the Croatian school system as follows: those who had been out of the system from 1-4 years and those out of it for 5 and more years. The assumption was that students who had been out of the Croatian school system for longer than 4 years would have lower scores on the c-tests. The results showed no difference between the students who had been in the school system for fewer than four years and those with more years away from the Croatian school system. Another test was conducted to see whether there was a difference between students with different backgrounds, i.e. mother tongues spoken at home. We assumed that students who speak Croatian, or Croatian +1 or more languages"at home would perform better on the c-tests than students whose mother tongue is not Croatian. The Kruskal-Wallis non-parametric test was conducted and it established that there was no statistically significant difference in the score on the first assessment task and languages spoken at home $\chi^{2}(2)=0.834, p=0.659$, and scores on the second assessment task and languages spoken at home $\chi^{2}(2)=1.289, p=0.525$.

\section{Summary and conclusion}

Due to English being their language of instruction, young Croatian heritage language learners in this research show a tendency to read more in the English language. In terms of genre, they show a rather indifferent attitude towards fairy tales, but also seem to like fairy tales in English more than fairy tales in Croatian, more specifically fairy tales by Ivana Brlić-Mažuranić. Although students are familiar with these fairy tales (almost half of the students in the sample), the majority express a cautious indifference towards reading them. This can be ascribed to the rich stylistic and linguistic aspects of the fairy tales, which, if not approached carefully, may cause anxiety and indifference in CHLLs.

In terms of literary elements which they find intriguing for engaging in reading fairy tales, CHLLs mention an interesting plot, dialogues and unpredictable endings. CHLLs find descriptions of setting, characters, even rich illustrations as stumbling blocks or simply overwhelming. Reading the first pages of the fairy tale "Reygoch" 
showed that CHLLs are mostly undecided in terms of making a decision to read on, and students are almost unanimous in recommending "Reygoch" for reading in upper primary and lower middle school grades. Differences were not established between CHLLs' reception of the fairy tale "Reygoch" with respect to the students' grade level, number of years out of the Croatian school system or mother tongue(s). Surprisingly for the authors, the students' comprehension of the initial pages of the fairy tale was not hindered by unknown words or unfamiliar sentence structures, and their comprehension of the text did not depend on their grade level, years of being out of the Croatian school system, or language(s) spoken at home.

The above findings suggest the need for an instructional agenda for teaching HLLs demanding literary texts. Their indifference towards fairy tales and fairy tale features across the board is a clear indicator to the teacher that it is indispensable to implement activities for HLLs which foster inquiry into aspects of vocabulary, syntax and contextualisation.

Due to the infancy of the field of heritage language acquisition in relation to Croatian learners, and, analogously, the embryo phase of research on young CHLLs, there are no significant research findings with which we could compare the findings of our research. Preliminary research of this kind, on a population of young Croatian heritage language learners, particularly with respect to their reception of Croatian fairy tales, has not been carried out. Considering that the sample size was relatively small and heterogeneous, exploring other research methodologies, mostly qualitative ones, a deeper text-level analysis, and using different techniques for testing reading comprehension in further research might lead to clearer explanations, stronger argumentations and consequently more precise recommendations for teaching. In addition, extending research to another school with a similar student body could potentially yield further results to identify commonalities among young CHLLs.

As the learning of a heritage language is a multifaceted endeavour, the methodological principles for both teaching and researching such a dynamic system should always consider what is comprehended and what is not, as well as the familiar and unfamiliar contexts in which that comprehension or lack of comprehension takes place (cf. Gass and Selinker, 2008). This specific group of young heritage language learners in Croatia has shed light on the need, perhaps even urgency, for a closer interdisciplinary approach to the methodology of literary scholarship and second language acquisition. With the goal of providing more beneficial instruction to HLLs, the two areas mentioned should simultaneously be considered: fostering understanding of the concept of fairy tales, and fostering interest in and appreciation for the Croatian language and culture. 


\section{References}

An, Shuyind. 2013. "Schema Theory in Reading". Theory and Practice in Language Studies 3 (1): 130-134.

Brlić-Mažuranić, Ivana. 2006. "Regoč" = "Reygoch". Transl. by Fanny S. Copeland. In Priče iz davnine: međunarodna bajkovita avantura, interaktivne priče, crtići, igrice, slavenska mitologija = Croatian tales of long ago: worldwide fairy tale adventure, interactive stories, cartoons, games, Slavic mythology = Kroatische Märchen aus Urväterzeiten; weltweites Märchenabenteuer, interaktive Märchen, Cartoons, Spiele, di slawische Mythologie. 2. CD ROM. Zagreb: Bulaja naklada.

Ewers, Hans-Heino. 2013. "Children's Literature in Europe at the Start of the $20^{\text {th }}$ Century and the Intellectual Place of Ivana Brlić-Mažuranić's Children's Story Čudnovate zgode šegrta Hlapića". Libri \& Liberi 2 (2): 179-186.

Gass, Susan M. and Larry Selinker. 2008. Second Language Acquisition. New York: Routledge.

Goodman, Kenneth S. (1967). "Reading: A Psycholinguistic Guessing Game”. Journal of the Reading Specialist 6 (1): 126-135.

Grahovac Pražić, Vesna and Anita Marijić. 2015. "Ivana Brlić-Mažuranić in Textbooks for Classroom Instruction”. Magistra Iadertina 9 (1): 39-54.

Grgić, Ana, Ranka Đurđević and Tanja Salak. 2015. Šegrt Hlapić za razinu B1: prilagodba romana Čudnovate zgode šegrta Hlapića Ivane Brlić-Mažuranić. Zagreb: Filozofski fakultet.

Hranjec, Stjepan, Andrijana Kos-Lajtman and Jasna Horvat. 2010. "Učenička recepcija mitološke geneze likova Priča iz davnine Ivane Brlić-Mažuranić”. In Društvo i jezik - višejezičnost $i$ višekulturalnost, edited by Ante Bežen, and Dunja Paličević-Franić, 100-114. Zagreb: Učiteljski fakultet, ENCSI.

Jelaska, Zrinka. 2014. "Vrste nasljednih govornika”. LAHOR 9 (17): 83-105.

Jurišić, Martina. 2014. “Knjiga Omladini Ivane Brlić-Mažurnić”. Kroatologija 5 (1): 69-90.

Katona, Lucy and Zoltan Dörnyei. 1993. "The C-test: A Teacher Friendly Way to Test Language Proficiency”. Forum 31 (2). Available from <http://www.zoltandornyei. co.uk/uploads/1993-dornyei-katona-etf.pdf> (accessed 30 April 2016).

Narančić Kovač, Smiljana. 2016. "Tales of Long Ago as a Link Between Cultures". The ESSE Messenger 25 (1): 93-107. Available from <http://essenglish.org/messenger> (accessed 27 November 2016).

Nastavni plan i program za osnovnu školu. (2006). Available from <public.mzos.hr/fgs. axd?id=14181 $>$ (accessed 26 November 2016$)$.

Read, John. 2000. Assessing Vocabulary. Cambridge: Cambridge University Press.

Schaetti, Barbara. 1993. "The Global Nomad Profile". In The Global Nomad: The Benefits and Challenges of an Internationally Mobile Childhood. Regents College Conference, London, 23 April.

Skok, Joža. 1995. "Čudnovate zgode šegrta Hlapića i Priče iz davnine Ivane BrlićMažuranić". In Ivana Brlić-Mažuranić. Daniel Defoe, written by Joža Skok and Milan Crnković, 5-146. Zagreb: Školska knjiga.

Turza-Bogdan, Tamara and Nina Kovač. 2015. "Recepcijske posebnosti i individualan doživljaj Šume Striborove i Regoča Ivane Brlić-Mažuranić u izvannastavnome čitanju”. In "Šegrt Hlapić” od čudnovatog do čudesnog: zbornik radova, edited by Berislav Majhut, Smiljana Narančić Kovač and Sanja Lovrić Kralj, 733-747. Zagreb and Slavonski Brod: Hrvatska udruga istraživača dječje književnosti, Ogranak Matice hrvatske Slavonski Brod. 


\section{Ivana Cindrić}

Sveučilište u Zagrebu, Učiteljski fakultet, Zagreb, Croatia

Fakultät für Lehrerausbildung der Universität Zagreb, Zagreb, Kroatien

\section{Vlatka Blagus}

Američka međunarodna škola, Zagreb, Hrvatska

Amerikanische Internationale Schule Zagreb, Zagreb, Kroatien

\section{Recepcija bajke „Regočc6 u nasljednih učenika hrvatskoga jezika}

Globalno povezano društvo koje karakterizira gotovo nomadski život nametnulo je potrebu za školovanjem djece u sustavima koji omogućuju međunarodno priznato obrazovanje, neovisno o državi u kojoj se učenici školuju. Tako primjerice Američku međunarodnu školu u Zagrebu (AISZ) pohađaju djeca različitih nacionalnosti, uključujući djecu hrvatske nacionalnosti ili hrvatskoga podrijetla. Iako ti nasljedni učenici hrvatskoga prate nastavu na engleskome jeziku, oni imaju i predmet Hrvatski jezik. Prema predmetnome kurikulu oblikovanome u skladu s potrebama učenika AISZ-a, u četvrtome i petome razredu obrađuju se i Priče iz davnine Ivane Brlić-Mažuranić. Ovaj rad prikazuje recepciju bajke „Regoč“ na primjeru heterogenih skupina učenika od šestoga do desetoga razreda. Za provjeru razumijevanja pretpostavljeno nepoznatih ili kontekstualno teže razumljivih riječi upotrijebljen je c-test. Rezultati istraživanja pokazuju da se djelo Ivane BrlićMažuranić može ponuditi na čitanje i inojezičnim učenicima hrvatskoga jezika uvažavajući osobitosti njihove recepcije. Analizom učeničkih odgovora stječe se uvid i u njihovu razinu književnoga čitanja te se opisuju individualne razlike među učenicima. Objašnjavaju se poteškoće na koje učenici nailaze dok čitaju izvorni književni tekst koji je zahtjevan na svim razinama književnoga čitanja. Također se predlažu strategije poučavanja kojima se takve poteškoće mogu izbjeći ili umanjiti.

Ključne riječi: bajka, c-test, nasljedni učenici hrvatskoga jezika, recepcija, „Regoč“

\section{Die Rezeption des Märchens Regoč unter Schülern mit Kroatisch als Herkunftssprache}

Die global vernetzte Gesellschaft, der beinah ein Nomadenleben eigen ist, erfordert eine Ausbildung von Kindern im Rahmen solcher Systeme, die einen international anerkannten und vom Standort unabhängigen Schulabschluss ermöglichen. Dementsprechend besuchen die Amerikanische Internationale Schule in Zagreb (AISZ) neben Kindern kroatischer Nationalität oder Abstammung auch jene unterschiedlicher nationaler Herkunft. Obwohl diese Kinder auf Englisch unterrichtet werden, belegen sie auch das Fach Kroatische Sprache und Literatur. Nach der Maßgabe des an die Bedürfnisse der AISZ-Schüler angepassten Lehrplanes wird in der vierten und fünften Klasse auch Ivana Brlić-Mažuranićs Werk Priče iz davnine bearbeitet. Im Beitrag wird die Rezeption des Märchens Regoč von Ivana Brlić-Mažuranić in gemischten Schülergruppen von der sechsten bis zur zehnten Klasse vorgestellt. Bei der Überprüfung des Verständnisses des Vokabulars, von dem anzunehmen war, es sei unverständlich oder schwer verständlich, wurde der C-Test angewandt. Die Forschungsergebnisse weisen darauf hin, dass das Werk von Ivana Brlić-Mažuranić 
auch fremdsprachlichen Teilnehmern am Kroatischunterricht unter Berücksichtigung der Besonderheiten der Rezeption dieses Textes zum Lesen anzubieten ist. Im Beitrag wird auch die durch die Analyse der Schülerantworten erworbene Einsicht ins Niveau, auf dem die Schüler literarische Texte zu lesen im Stande sind, vermittelt, wobei auf individuelle Unterschiede zwischen den Schülern eingegangen wird. Ferner werden im Beitrag Schwierigkeiten erklärt, mit denen Schüler beim Lesen dieses anspruchsvollen literarischen Textes konfrontiert waren, sowie Lehrstrategien vorgeschlagen, mit deren Hilfe man diese Schwierigkeiten ausklammern oder zumindest vermindern kann.

Schlüsselwörter: C-Test, Märchen, Regoč, Rezeption, Schüler mit Kroatisch als Herkunftssprache 

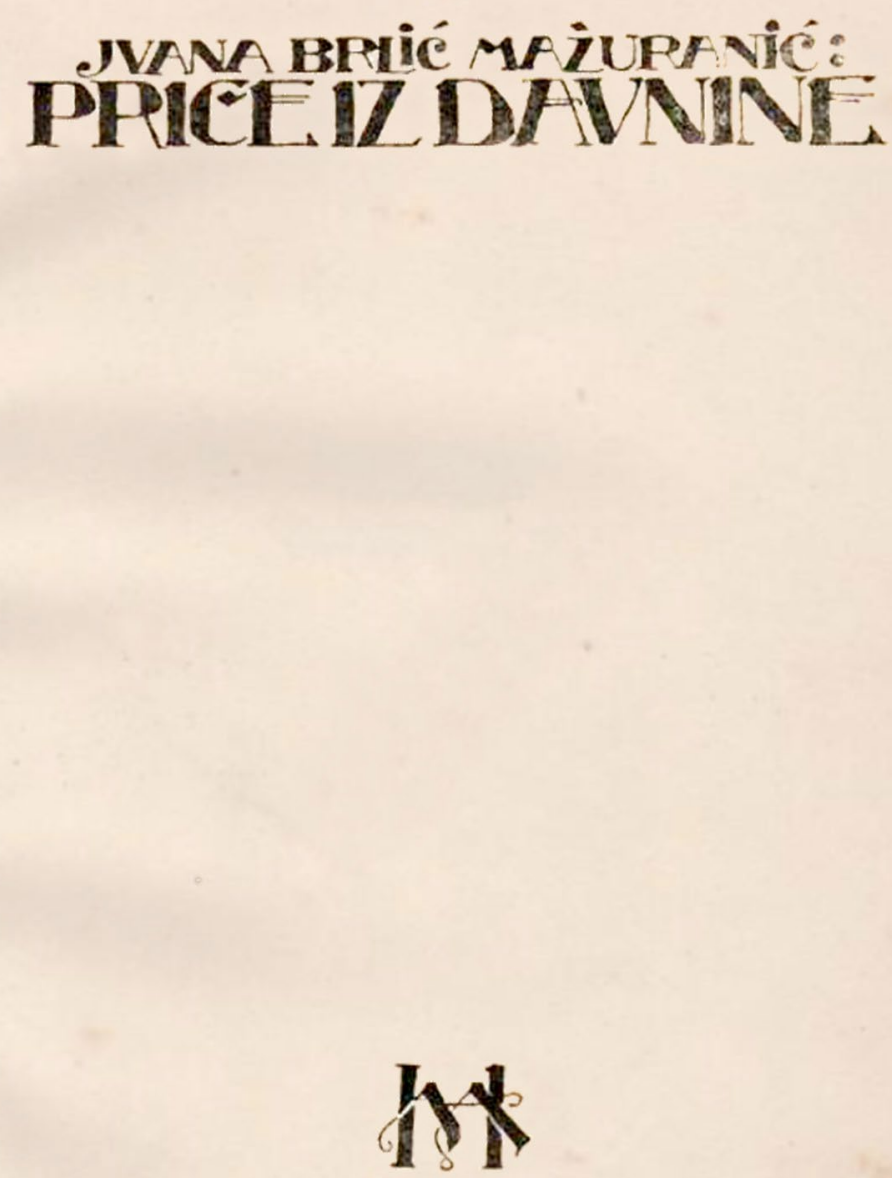

-ZAGPER. 1986.

The title page of the first edition of Priče iz davnine [Tales of Long Ago] by Ivana Brlić-Mažuranić (1916).

Naslovnica prvoga izdanja Priča iz davnine Ivane Brlić-Mažuranić (1916). 